\title{
LATIP 2021
}

International conference «Language and technology in an interdisciplinary paradigm»

\section{COVID-19 REALITIES IN YAKUT MEDIA TEXTS}

\author{
Tatiana Nikolaeva (a)*, Anna Pribylykh (b) \\ *Corresponding author
}

(a) North-Eastern Federal University, 58, Belinsky str., Yakutsk, Russia, tnikolaeva184@mail.ru (b) North-Eastern Federal University, 58, Belinsky str., Yakutsk, Russia, annapribylykh14@gmail.com

\begin{abstract}
This research paper discusses and considers the language representation of COVID-19 terms in the Yakut media texts. It reveals that a language transfer of information about a new situation is characterized by the presence of neologisms, change and update of the meanings of existing words in contexts associated with a changed reality, transition of medical terms from the professional field to the sphere of mass use. The research sources are articles from "Kyym" and "Sakha Sire" local newspapers. The results of the study record the emergence of new words and the revitalization of previously uncommon words; it also allows to track the reaction of native speakers of the Yakut language to lexical and semantic and word-formation innovations. These results followed an online survey that was conducted among five age groups of Yakutia's population, covering about 350 respondents. The survey showed that middle-aged informants rather prefer the nomination of this infection as 'ковид' (covid) than, for example, 'коронавирус' (coronavirus) for the language economy reasons. Among older respondents, the most frequent was an outdated word 'хамсык', the appearance of which on the pages of local newspapers was recorded in March 2020. Recently, its widespread use has been noticed in the speech of presenters and journalists of local TV and radio channels. Along with this word, the use of the originally "infectious" lexical unit 'дьан', which previously reminded of its existence in information bulletins during the spread of an acute respiratory viral infections and influenza, has noticeably increased.
\end{abstract}

2357-1330 @ 2021 Published by European Publisher.

Keywords: Borrowings, COVID-19, linguistic means, media text, neologism, the Yakut language 


\section{Introduction}

The present life of the humanity is marked by a close attention to a new infection, which suddenly made its own adjustments in the life of every person both literally and figuratively. People talk, write, discuss, curse about this infection, which has swept the whole world, using all kinds of verbal and nonverbal means of communication in different languages. A new infection invaded the lives of people under the official name COVID-19, however, as reality shows, it was not limited to this nomination only. The new abbreviation as a linguistic unit contributed to the widespread distribution of other terms that were not as active until that time, such as "epidemic", "pandemic", "isolation", as well as neologisms borrowings "coronavirus", "lockdown", which turned out to be key concepts in modern life. Thus, we are not only users of newly appeared words and phrases, but have witnessed the process of the emergence of new phenomena, their nominations and entries into languages, as well as their adaptation in the conditions of the adopting language or languages.

\section{Problem Statement}

The present study is an attempt for a linguistic understanding of the COVID-19 pandemic based on the examples of Yakut print media. The ongoing processes in vocabulary and word formation immediately began to be actively discussed on the material of different languages. Olga Severskaya (2020) wrote in her research: "neologisms of English, German and French are studied. And, paradoxically, the least linguistically measured is the Russian language material" (pp. 889-890). According to other authors, "The linguistic understanding of this reality is already actively carried out in Russian studies and on the material of different languages, for example, English, Belarusian, Polish and German, Russian and Chinese in a comparative aspect". The authors also noted the presence of works which are devoted to the "coronavirus" phenomena of language in different types of discourses - in political discourse, in media discourse, in Internet communication, etc. They concluded "the research on this language material in the field of lexicography and sociolinguistics is developing" (Radbil et al., 2021, p. 64).

To date, many works are devoted to the presentation of COVID-19 in media discourse (Dankova \& Krekhtunova, 2020; Karasik, 2020; Malkova, 2020; Parvin et al., 2020). The Yakut mass media also began to cover this topic actively. In a short period of time, vague new words and expressions began to appear, and the interpretation of the new reality was noticeably intensified due to the potential of common existing lexemes.

\section{Research Questions}

This research focuses on tracking the linguistic representation of the COVID topic on the pages of Yakut newspapers for 2020 and the 1st quarter of 2021, that is, from the beginning of the large-scale spread of infection from east to west, and from there through central Russia to Yakutsk and further across the republic. In parallel with the boundaries expansion of the disease's spread, new words and expressions of foreign origin began to appear, nominating the infection and everything that accompanies it and what is 
caused by it. Thus, at first, the entire communicative sphere began to broadcast information in the language of a new infection. Neologisms that arose in a wide information field entered the functional Yakut language, including in the media language. As mentioned above, the attention of linguistic research was immediately riveted to this phenomenon, which allows us to highlight the levels of monitoring of the relevant naming of given infection in the Yakut information space.

\section{Purpose of the Study}

The purpose of this study is to identify the features of the processes caused by the spread of COVID-19 in the modern Yakut language on the semantic, lexical, word-formation levels, that is, to track which new words and expressions have entered into the media language, which existing words and expressions have acquired a new meaning and use, which derivational models have turned out to be productive for reflecting the dynamics of the representation of linguistics phenomena in real time.

The examples of this research were drawn as a result of monitoring the materials of articles in the context of the new reality, published in the local top-rated newspapers.

\section{Research Methods}

The research is carried out by the combination of observation methods, lexical-semantic and syntactic analysis of linguistic units, which were retrieved from articles from "Kyym" and "Sakha Sire" Yakut newspapers in 2020 and 2021. The object of this research is the language changes caused by the spread of COVID-19.

\section{Findings}

The study revealed that the linguistic coverage of the problems associated with the disease in question is carried out mainly through the following methods:

\subsection{Neologisms, borrowings}

The nature of the new words and expressions that emerged in the wake of the COVID-19 crisis investigated and analysed many researchers (Asif et al., 2020; Mweri, 2021; Saleh \& Haider, 2021).

In the Yakut media discourse the most preferred term for designation of this infection is the English abbreviation "COVID-19" (Coronavirus disease 2019), although, according to monitoring data, in the beginning such designation as "коронавирус" (coronavirus) was the most widespread. For example, "Россияқа COVID-19 утары охсуһууга көмөлөһүөн сөптөөх үс эми онордулар" (Three drugs have been invented in Russia that can help fight COVID-19); "Саха сиригэр коронавирус суох" (there is no coronavirus in the Republic of Sakha); "коронавирус Саха сиригэр тиийэн кэллэ” (Coronavirus reaches the Republic of Sakha).

According to the analysis, in newspaper articles there is a parallel use of phrases "коронавирус эпидемията" [koronavirus epidemijata] (coronavirus epidemic), “коронавирус инфекциятын тарқаныыта" [koronavirus infektsijatin tarğaniita] (spread of coronavirus infection), “коронавирус 
пандемията" [koronavirus pandemijata] (coronavirus pandemic), which in the linguistic consciousness of the Yakuts appear as combinations that completely coincide in meaning in a certain context. Thus, the formation of various kinds of collocations is caused by the novelty and unconsciousness of new lexemes, terms of foreign language origin: “Аан дойду үрдүнэн коронавирус эпидемията туран” (With the emergence of the coronavirus epidemic around the world); "Дьаһал коронавирус инфекииятыны тарқаныbытын утары сэрэтэр үлэни кытта сибээстээх" (The order is related to work to prevent the spread of coronavirus infection); “коронавирус инфекцията тарБаныьытын сэрэтиигэ суһал штаб тэрилиннэ" (An operational headquarters for the prevention of the spread of coronavirus infection has been created); “Коронавирус пандемиятынан, Саха сиригэр атын регионтан кэлээччилэр, 14 хонуктаах харантыыны ааһаллара булгуччулаах" (In connection with the coronavirus pandemic, those who come to Yakutia from other regions are required to undergo a 14-day quarantine); “коронавируснай тылмныйыbыны" (coronavirus cold).

The Kyym newspaper article makes an attempt of structural transformation of the "coronavirus" term to "a virus of corona", as shown in the following example, "сарсыардаанны брифиннэ Ил Дархан хоруона-вируһугар өссө үс киһи анаалыһа бигэргэммитин туһунан иһитиннэрдэ" (at the morning briefing, the head of the region said that tests for the 'virus of corona' of three people were confirmed to be positive).

It is noticed that in the Yakut media texts the neolexeme "ковид" (covid) is used very rarely in comparison with the Russian language, into which it not only entered, but also began to form new words according to the derivational models of the language.

Interesting from the cognitive linguistic point of view is a combination of the "self-isolation" lexeme with the word "regime", which was borrowed in this context from the Russian language and found its use on the pages of Yakut newspapers in its original form of writing, but in quotes: “Самоизоляция" эрэһиимэ 65-тэн үөһэ саастаах олохтоохторугар булгуччулаах буолла" ("Selfisolation" regime has become mandatory for residents over 65 years); “Дьокуускайга «самоизоляция» эрэһиимэ олохтонно" (In Yakutsk has been established a regime of "self-isolation").

The combination of the "self-isolation" lexeme with the word "regime" is perceived as an order for home isolation imposed from above, which is subject to regulation and control. In Yakut media texts it is often directly understood as "sitting at home" (stay-at-home regime): "Мукучу олохтоохторо дьиэқэ олоруу быыһык кэмигэр доруобуйаларын бөьөргөтүнэллэр" (Residents of the village of Mukuchu improve their health during stay-at-home regime); “Бэрэсидьиэн В.Путин быһаарыытынан бары биир ыйдаах “дьиэқэ олорууга” бардыбыт” (By the decision of President Vladimir Putin, we are going to the "stay-at-home" regime).

\subsection{Actualization of common words}

According to the newspaper "Sakha Sire", starting from March 2020 the lexeme "дьан [djay]" has been used to denominate the COVID-19 infection. It is originally known to the native speaker as "a rapidly spreading infectious disease, epidemic". One should note that this word was not frequently used before in the contemporary Yakut language, but as monitoring shows, it quickly began to acquire its relevance in the context of the changed reality. In the examples, the use of the lexеmе "дьан" is allowed 
both with and without reference to the key concept of COVID-19. For example, “медицина тэрилтэлэригэр дьан тарқаныыытын утары эбии миэрэлэр ылылыннылар" (additional measures were taken against the spread of the epidemic in medical institutions); “Трутнев Чайындақа COVID-19 дьана салгыы тарқаныытын таһаарбаттарыгар сорудахтаата" (Trutnev instructed to prevent further spread of the COVID-19 epidemic in Chayngda); "Коронавирус дьанын кытта охсуһар медицина үлэһиттэрэ" (Healthcare workers fighting the epidemic of coronavirus).

Actualization of the meaning of this lexeme in most cases is accompanied by the adjective “сыстыганнаaх" [sistigannaax] in the meaning of "contagious, carrying an infection", which gives the phrase a degree of special danger, even though actually there is a duplication of a certain semantic element: “ааспыт сууккақа эбии 52 киһи сыстыганнаах дьаннға сутулунна” (an additional 52 people have become infected with an infectious epidemic in the last 24 hours); "37 киһи сыстығганнаах дьаннга сутуллубута билиннэ" (It became known that 37 people were infected with an infectious epidemic); "Коронавирус: 116 киһи сыстыганнаах дьаннга сутулунна, икки ыарыһах ыарахан туруктаах" (Coronavirus: 116 people became infected with a contagious epidemic, two of them are in a serious condition).

In connection with the linguistic render of the new reality, the usage of the "хамсык" [hamsik] lexeme has noticeably intensified. It should be noted that according to the Explanatory Dictionary of the Yakut language, this word is considered outdated and means "pestilence, loss of cattle". In the Buryat language the word 'хамшаг' means 'epidemic', in the Tuvan language 'камдьык' has a meaning of 'plague, infection' (Sleptsov, 2016). In its modern meaning, this word acquires a "second wind" in a different context, expanding the scope of its use. It must be assumed that the observed semantic shift of the word, in this case the expansion of its meaning, occurs due to extralinguistic factors that caused its semantic transformation: "Хамсыгы утары быһыы бастакы түһүмэқин 54 тыһыынча киһи ылла" (The first stage of vaccination against the coronavirus epidemic passed 54 thousand people); "Хамсык дьана турбутунан сибээстээн” (Due to the coronavirus epidemic); “Хамсыгы кыайыахпыт, ол биһиги барыбыт кыайыыбыт буолуоқа!" (We will defeat the epidemic, this will be our common victory!); "Хамсык дьана тарқаныақыттан өрөспүүбүлүкэБэ 31 тыһ. тахса киһи ыарыйда" (Since the beginning of the spread of the coronavirus epidemic in the republic, more than 31 thousand people fell ill).

According to the above publications, the usage of medical terms such as 'quarantine, observator, sick leave, temperature measurement, protective mask, disinfection, doctor, symptom, high temperature, patient, analysis, medic', etc. became noticeable: "Учуонайдар 14 күннээх харантыылн наадатын бигэргэттилэр" (Scientists have confirmed the need for 14-day quarantine); "Үгүс улууска обсерватор бэлэм буолла"/ (Observators are ready in many districts of the republic); "Ньурбалар Кытай норуотуттан дьантан харыстанар мааскалары туттулар" (Nyurba received protective masks from China); "Маасканы сөпкө кэтиэххэ" (Let's put on the mask correctly); "Үрдүк температура. ВОЗ коронавирус бастакы сибикитин эттэ" (Hyperthermia. WHO named the first sign of coronavirus); "Улуустарга элбэх кыбартыыралаах дьиэлэри дезинфекииялыыр сириэстибэлэри тириэрдиэхтэрэ" (Means for disinfection of apartment buildings will be transferred to the regions of the republic); “коронавирустаахтарын билэр эрээри, мааскаларын усталлар, итинэн медищинскай персоналга 
кутталы үөскэтэллэр" (Knowing that they are sick with coronavirus, they take off their masks, thus they pose a danger to medical personnel); "Коронавируһу кытта охсуһар быраастарга кулун тутардаађы төлөбүр барыллаан 20 мөл солк тэн" (The total payment to doctors for the fight against coronavirus will be 20 million rubles for March); “Алданнаађы балыыһақа биэс ИВЛ апnараатын тиксэрдилэр” (Five ventilators delivered to the hospital of Aldan); “Алдан киин балыыһатын инфекционнай отделениетыгар 11 пациент баaр" (There are 11 patients in the infectious diseases ward of the Aldan hospital); "Саха сиригэр медиктарга анаан харыстанар көстүумнэри тигиини сақалаатылар" (Protective suits for doctors began to be sewn in Yakutia); "Бүгүн Алданна коронавирус анаальы hын ылар лаборатория арыллар" (A laboratory to test for coronavirus opens in Aldan today); “Офтальмология балыыһатын ыарыһахтарын обсерваторга киллэрдилэр” (Ophthalmology hospital patients placed in observatory).

\subsection{Derivational models}

In the analyzed newspaper articles we can observe a number of verbs derived from other parts of speech with the use of affixes, in particular, from the word "coronavirus" using "noun +"-таa" affix" model -> "коронавирустаa" [koronavirustaa] (to be ill with coronavirus): "Саха сиригэр ааспыт сууккађа 81 киһи эбии коронавирустаата, 12 киһи дьантан үтүөрдэ, биир киһи суорума суолланна" (In Yakutia, over the past day, 81 people became infected with coronavirus, 12 people recovered from the epidemic, one person died).

The participial form with '-быт' [bit] as a verbal adjective is equally common: “Ханаласка коронавирустаабыты кытта алтыспыт 74 киһи баара билиннэ" (In Khangalas it became known about 74 people, who were in contact with a coronavirus patient); “Саха сиригэр барыта 385 коронавирустаабыт киһи баар" (In Yakutia there are a total of 385 people with coronavirus).

In some cases we can observe an adverb with '-aн' used with an additional 'баран' [baran] form combined according to the "adverbial participle + adverbial participle" model. For example, “коронавирустаан баран бэйэлэрэ эмтэнэ сатааччылар" (getting sick with coronavirus, trying to heal on their own).

\subsection{Literal translation of words, phrases, expressions}

The process of new words introduction into the Yakut language is marked by their adaptation through literal translation according to formal or semantic features: Сана оноһук вируһy утары охсуһар (fights against a new artificial virus); Коронавирус иккис долгуна хайдах ааһыай? (How will the second wave of coronavirus go?); Хас биирдиибит мааска эрэсиимин уонна соииальнай дистанцияны тутуһуохтаахпыт (Everyone should wear a protective mask and maintain social distance); Хамсыгынан сибээстээн үлэ биэрээччилэр үлэһиттэрин ыраахтан үлэБэ (“удаленка5а”) көһөрөн эрэллэр (Due to the coronavirus, employers transfer workers to distant work ("remote"); ыарыыны утары ыытыллар миэрэлэри тутуһуу боппуруоһа биир бастакынан турарын, ыарыы симптомнарын, тымыр капиллярдарыгар дьайыытын уонна симптома суох ыарыыны тарқатааччылар баар буолуохтарын сөбүн эттэ (the issue of compliance with measures to combat the disease is in the first place, the symptoms of the disease, the effect on the vascular capillaries and there is 
a likelihood of the spread of the disease in asymptomatic patients); “Бастакы вакцина от ыйын бүтүүтэ баaр буолуоқа" (The first vaccine will be at the end of July); Россия олохтоохторугар COVID-19 утары быhыьы биэриитэ 2021 сылга сақаланыан сөп (COVID-19 vaccination for residents of Russia may begin in 2021).

In some cases, when transferring abbreviations (abbreviations), the preservation of the abbreviation adopted in Russian is noted, for example, “ИВЛ" (artificial lung ventilation), "ВОЗ" (world health organization): Алданнаақы балыыһа5а биэс ИВЛ аппараатын тиксэрдилэр (5 artificial lungs ventilation machines were transferred to the Aldan hospital); ВОЗ коронавирус бастакы сибикитин эттэ ( $W H O$ called the first signs of coronavirus).

As known, the general information about events is conveyed through the mass media, thus the newspapers show interaction between different discourses, in particular medical, political, economic, legal and other, which have pragmatic function of influencing the reader. The current situation is characterized by a ubiquitous communicative unity, involvement of the population in the development of innovations in all segments of industry and an enormous speed of information distribution. In this regard, we conducted a survey to identify how COVID-19 is perceived and to determine the degree of use of its nomination in the Yakut language among the adult population. An online questionnaire was sent to the informants, where the respondents submitted personal information and answered the question which nomination of COVID-19 in Yakut is preferable to them. In total 350 people were interviewed, they were divided into 5 groups according to their age: 1) from 16 to 25 ; 2 ) from 26 to 35 ; 3 ) from 36 to 45 ; 4) from 46 to 55 ; 5) from 56 and older.

In general, the analysis of the collected material revealed the following:

1) In all groups, respondents do not often use the "coronavirus" lexeme in their speech. Presumably, this is due to a complex component structure, which is not in favour of language economy.

2) In the second, third and fourth groups, preference is given to the word “ковид" (covid), but the older the group is, the less often it is used.

3) The lack of the "ковид" (covid) lexeme use in older groups is compensated by the Yakut "хамсык" lexeme, which has acquired a relevant meaning in the new conditions.

4) The lexeme "ковид" (covid) turned out to be the most frequent, which is explained by the dominance as a unit, which was assimilated and quickly adapted at the lexical-semantic level in Russian, and then in the Yakut language.

5) Attention is drawn to the fact that respondents highlight words that are familiar to them and have become relevant, since they have now undergone a certain semantic shift in their use. These include the lexemes "хамсык", “дьан". Interesting is the use of the word "сэбиргэхтэтии" [sebirgextetii] in the meaning of 'pneumonia', as it has a colloquial status, it is not found in newspaper articles. However, the respondents record this lexeme as an option for the practice of use.

6) The lexeme "корона" [korona] (crown) is used by a group of informants aged 26 to 35 .

\section{Conclusion}

In general, the analyzed linguistic material showed the reaction of the modern Yakut language to the events of the new reality. The current situation is characterized by the transience and unpredictability 
of the ongoing processes, which require a meaningful interpretation of their meanings through the nomination and through the understanding of the essence in languages. In our opinion, such innovative words as, for example, social distancing (distance), lockdown, self-isolation, pandemic and others that quickly spread in the communicative and media space have not found an adequate linguistic adaptation as objects of nomination due to terminological uncertainty, difficulty in their translation, or lack of equivalents. To form the COVID situation nominations, the Yakut language chose the preferred ways of naming key concepts, which is confirmed by their frequency in newspaper texts. Out of a number of competitive names, this language selects the entries that correspond to linguistic economy conventions. Noticeable is an increasing role of broadening of the scope of the original lexemes usage that acquires new meanings or connotations in another category.

\section{Acknowledgments}

The authors gratefully acknowledge participants of the survey.

\section{References}

Asif, M., Zhiyoung, D., Iram, A., \& Nisar, M. (2020). Linguistic Analysis of Neologism Related to Coronavirus (COVID-19). https://papers.ssrn.com/sol3/papers.cfm?abstract_id=3608585

Dankova, N. S., \& Krekhtunova, E. V. (2020). Media Representation of the Pandemic: a Metaphorical Image of War (based on American Newspapers). Nauchnyj dialog, 8, 69-83.

Karasik, V. I. (2020). Epidemic in the Mirror of Media Discourse: Facts, Evaluations, Positions. Political Linguistics, 2(80), 25-34.

Malkova, V. K. (2020). Coronavirus in the Russian Mass Media. Vestnik antropologii, 2(50), 206-224.

Mweri, J. (2021). Corona Virus Disease (COVID-19) Effects on Language Use: An Analysis of Neologisms. Linguistics and Literature Studies, 9(1), 36-47.

Parvin, G., Rahman, Md. H., Ahsan, R., \& Abedin, Md. A. (2020). Media Discourse About the Pandemic Novel Coronavirus (COVID-19) in East Asia: The Case of China and Japan. https://papers.ssrn.com/sol3/papers.cfm?abstract_id=3603875

Radbil, T. B., Ratsiburskaya, L. V., \& Paloshi, I. V (2021). Active Processes in the Vocabulary and Word Formation of the Russian Language in the Era of Coronavirus: Linguo-Cognitive Aspect. Nauchnyi dialog, 1, 63-79.

Saleh, A-S., \& Haider, A. S. (2021). COVID-19 trending neologisms and word formation processes in English. Russian Journal of Linguistics, 25(1), 24-42.

Severskaya, O. I. (2020). Covidiots on coronacation: coronaviral lexicon as a diagnostic field for actual discoursive practices. Kommunikativnyye issledovaniya, 7(4), 887-906.

Sleptsov, P. A. (2016). Large explanatory dictionary of the Yakut language: in 15 volumes. Vol. 8. Novosibirsk, Nauka. 